\title{
SOMNOLOGICAL FINDINGS BASED ON THE KÖRMEND GROWTH STUDY (2008) DATA (HUNGARY)
}

\author{
Botond L. Buda ${ }^{1}$, Lilla Marksz ${ }^{2}$, GÁbor A. Tóth ${ }^{3}$ \\ ${ }^{1}$ Private Practice for Neurosomnology, Szombathely, Hungary \\ ${ }^{2}$ Gedeon Richter Plc, Budapest, Hungary \\ ${ }^{3}$ ELTE, Savaria University Centre, Szombathely, Hungary
}

\begin{abstract}
In 1958, a series of tests repeated every ten years, which is unique worldwide, was launched in Körmend, with the primary goal of assessing more than 20 different body size characteristics, constitution, and development of healthy children aged 3-18. The secular trend phenomenon was proved for the first time in Hungary in this study. A clear correlation between physiological sleeping and sleeping disorders compared to changes in body composition has been shown, which led to the inclusion of a sleep questionnaire study in 2008 . The present study aims to analyze a part of the sleep questionnaires received in 2008. The aim of this study was to investigate the presence and frequency of growth pain, restless leg syndrome (RLS) and anaemia, and the associations between these parameters. According to the results, the incidence of growth pains was found to be higher than in international data. In many aspects this difference was confirmed by the present study, however, there were also contradictory, significantly detectable differences, the causes of which require further investigation. Due to the limitations of the questionnaire, many errors may occur. Other studies have shown strong genetic determinations for RLS; however, our results do not seem to confirm this. This may be due to the high latency of RLS and the inaccurate filling of the questionnaires as well. The results of our study showed that, in iron-deficient children, the incidence of RLS is an order of magnitude higher than in the general population.
\end{abstract}

Keywords: Körmend Growth Study; sleep disorders 


\section{INTRODUCTION}

One of the fundamental roles of sleep is saving of energy [59]. Its most important functions are rest and regeneration [8]. Research on sleep disorders began to emerge in the late 20th century [5]. Investigating the relationship between sleep disorders and changes in body size, body composition and body constitution has become a priority research area in recent decades [10, 35], including children and adolescents. The Körmend Growth Study [22], which is unique worldwide, was launched in 1958 and is repeated every 10 years. It revealed some of these factors and described some areas of the previously observed [57] secular trend phenomenon [48, 49]. Children's physical development is greatly influenced by their living conditions. Obstructive sleep apnoea [56] is strongly related to obesity; thus, it is more and more often seen in children [27] with overweight. Approximately $40 \%$ of toddlers have pulsating, sore lower limb pain from the age of 2-3 years, but mainly from the age of 4-6 years [23] and up to 12-14 years [41, 47]. Benign childhood musculoskeletal disorders, most often occurring in the late afternoon, early morning, or at night, are referred to as growth pain in the literature [19]. It is also rarely associated with headache or abdominal pain [53]. In most cases, the onset of growth pains does not coincide with the time of the most rapid "growth spurt" in adolescence [1]. A growing number of studies have highlighted the clinical similarity and possible pathophysiological and genetic associations between growth pain and the restless leg syndrome and periodic limb movement disorders during sleep [20, 43], also suggesting the possibility of identity [58].

The restless leg syndrome is a characteristic awry limb sensation that is accompanied by movement urge [7]. Symptoms occur at rest and usually from dusk until dawn [12, 32, 38]. Physical activity reduces the signs [4]. All this causes one-third of chronic sleep deprivation. Falling asleep takes more time, the proportion of superficial sleep increases compared to deep sleep, and the duration of REM sleep is also reduced. Frequent micro-awakening results in the disruption of healthy sleep patterns $[9,51]$.

In $25 \%$ of adults with RLS, the onset of the disease can be attributed to childhood or adolescence [40]. Early childhood growth pain was reported in $80.6 \%$ of children and adolescents with RLS, compared with only $63.2 \%$ of healthy children. This overlapping with growing pains in children results in the fact that the clinical characteristics of paediatric RLS have not been studied enough [28].

There are several explanations for the origin of the disease. Lim et al. [31] attribute the greater role to the somatosensory processing system. Some data 
point to thin-fibre neuropathy [26], others to opioid dysfunction [46], and, over the decades, numerous observations have supported the significant role of dopaminergic dysfunction [37]. There are also idiopathic and symptomatic versions of the syndrome, which can be attributed to different causes and how they occur. Clinical experiences confirm that iron deficiency, anaemia [18] and renal diseases $[36,52]$ play a major role in the development of RLS.

In case of Periodic Limb Movements in Sleep (PLMS), involuntary movements are associated with the first and the second stage of sleep, followed by awakening. This prevents getting into deep sleep phases [60]. PLMS also occurs in $50-80 \%$ of patients with RLS [25,34]. PLMS can be genetic or symptomatic. In the latter case - as with RLS - the common causes are iron and folic acid deficiency, anaemia, and renal failure [2]. Night-time sleep quality and daytime somnolence assessment may be helpful in diagnosing PLMS. Further assistance may be provided if a fellow observes the patient's limb movements.

\section{METHODS}

Various questionnaires can be used to assess daytime sleepiness to diagnose the restless legs syndrome. These include the Epworth and Stanford Scales or the subjective drowsiness test. PLMS cannot be assessed by questionnaires, as the subjects are unaware of this, and their most common accompanying symptoms are frequent night-time awakenings and daytime somnolence.

In the Körmend Growth Study, studies have been conducted eight times (1958, 1968, 1978, 1988, 1988, 1998, 2008 and 2018). A large number of samples of children aged 3-18 years were examined; their growth, somatic changes, maturation tendencies were analyzed $[21,50]$. The sleep study was conducted only during the 2008 study [13]. The inclusion of the study was necessary because the association between sleep deprivation and obesity had been proven in the meantime $[15,17]$.

The aim of the current research is to summarize, systematize and search for the data of the somnological questionnaire of the Körmend Growth Study carried out in 2008. The questionnaire consisted of concise and straightforward questions, most of which were closed (with pre-defined answers). The questions were fully in line with the questionnaire structure and with international recommendations [4]. 
There were four options for answering the questions about the incidence of symptoms:

- often (several times a day or several times a week)

- occasionally (1-2 times a month)

- less frequently (less than 1 per month)

- never

The first question was about the incidence of growth pain in childhood. Next, it asked about the presence, frequency or absence of complaints specific to the restless legs syndrome. The third module consisted of 4 parts with the aim to provide the basic criteria for accurate diagnosis of the restless legs syndrome. They required yes-no answers. Questions 4, 5 and 7 also helped to determine whether it really was the restless leg syndrome. Module 6 was designed to map family accumulation in restless legs syndrome, periodic limb movement in sleep, and severe sleep disorders. The last question asked about iron deficiency and/or anaemia.

A total of 1094 questionnaires were completed. Of this, 736 (67.3\%) were from the primary school age group (6-15 years of age, mean 10.0 years, SD 2.4 years. (In this study, the data from questionnaires completed by primary school children were processed.)

The research sought answers to the following questions:

1. According to the answers to the questionnaires, how frequent is childhood growth pain among children aged 6-15 in Körmend?

2. According to the answers to the questionnaires, what is the prevalence of the restless legs syndrome among children aged 6-15 in Körmend?

3. Based on the answers to the questionnaires, can the restless legs syndrome and other sleep disorders (insomnia) be hereditary?

4. Based on the responses to the questionnaires, can we identify any association between childhood growth pain and the onset of the restless legs syndrome?

5. According to the answers to the questionnaires, what is the prevalence of iron deficiency and iron deficiency anaemia in children aged 6-15 in Körmend?

6. Based on the answers to the questionnaires, do we find a correlation between iron deficiency and anaemia in children and the onset of the restless leg syndrome?

Statistical analyses were performed with Microsoft Excel [44] and Statistical Package for the Social Sciences (SPSS) [30]. 


\section{RESULTS}

\section{Occurrence of growth pains}

According to the Körmend Growth Study 2008 Sleep Questionnaire, out of 736 correctly completed questionnaires, 18 children (2.5\%) had growth pains daily or multiple times a week, 97 children (13.1\%) 1-2 times a month, 238 children (32.3\%) had growth pains more seldom, and 379 children (51.5\%) did not experience any such pain. By gender, 9 of 354 boys ( $2.5 \%$ of boys) reported pains daily or multiple times a week, 44 (12.4\% of boys) reported them 1-2 times a month, and 112 boys (31.6\%) had less frequent growth pains, 184 boys (52.0\% of boys) had them never. Of the 382 girls who responded, 9 (2.4\% of girls) had pains frequently (daily), 53 (13.9\% of girls) occasionally (once or twice a month), 125 (girls) 32.7\%) rarely, 195 (51.1\% of girls) had never experienced growth pain (Figure 1).

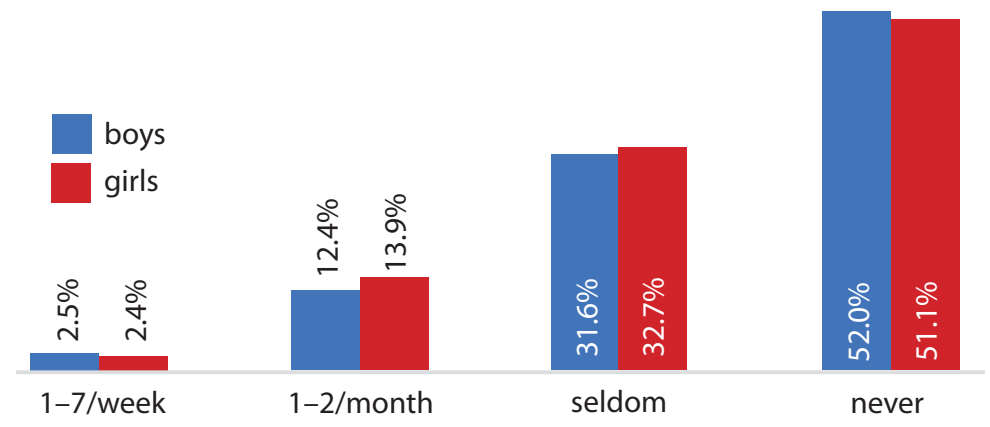

Figure 1. Incidence of growth pain in boys and girls

\section{Occurrence of the restless legs syndrome}

Concerning the restless legs syndrome (RLS), 14 out of 736 patients $(2.0 \%)$ had it frequently, 57 (7.7\%) 1-2 times a month, 173 (23.5\%) less frequently, 482 children (65.5\%) had never experienced the disease.

By gender (Figure 2), 6 out of 354 boys (1.7\% of boys) had frequent RLS symptoms, 24 ( $6.8 \%$ of boys) had it 1 to 2 times a month, 78 ( $22.0 \%$ of the boys) had fewer complaints, and 239 (67.5\% of the boys) had no complaints at all. Of the 382 girls, 8 ( $2.1 \%$ of the girls) had RLS symptoms daily or more than once a week, 33 (8.6\% of the girls) had an RLS estimate of 1-2 times a month, 95 (24.9\% of the girls) reported it less frequently, and 243 (63.6\% of the girls) had no symptoms at all. 


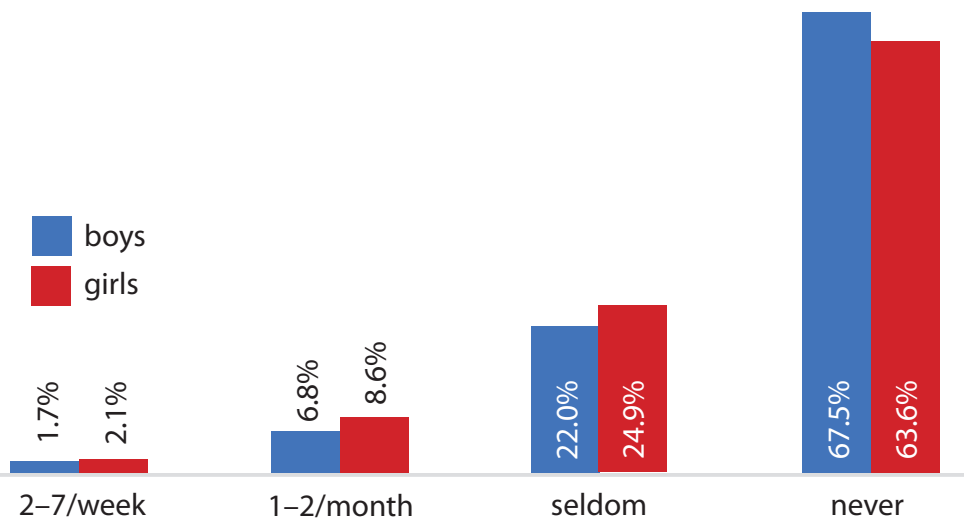

Figure 2. Prevalence of RLS symptoms in children in Körmend

\section{Fulfilment of the basic criteria for RLS}

To alleviate complaints, 132 children (17.9\% of the total sample and $54.1 \%$ of those reporting RLS symptoms) actively moved their legs. The exercise relieved the discomfort in 147 children (20.0\% of the total sample and $60.2 \%$ of the RLS complainants). Prolonged immobility resulted in worsening in 120 children ( $16.3 \%$ of the total sample and $49.2 \%$ of those reporting RLS). Diurnality was observed in only 61 children ( $8.3 \%$ of the total sample and $25 \%$ of those reporting RLS).

The answers to question 3 by gender were as in Table 1 .

Table 1. Results of the RLS symptom questions

\begin{tabular}{|c|c|c|c|c|c|c|}
\hline & \multicolumn{3}{|c|}{ boys } & \multicolumn{3}{|c|}{ girls } \\
\hline & $\mathbf{n}$ & $\begin{array}{l}\% \text { of } \\
\text { boys }\end{array}$ & $\begin{array}{l}\% \text { of RLS } \\
\text { boys }\end{array}$ & $\mathrm{n}$ & $\begin{array}{l}\% \text { of } \\
\text { girls }\end{array}$ & $\begin{array}{l}\% \text { of RLS } \\
\text { girls }\end{array}$ \\
\hline $\begin{array}{l}\text { Because of discomfort, they } \\
\text { actively move their legs }\end{array}$ & 54 & 15.3 & 50.0 & 78 & 20.4 & 57.4 \\
\hline $\begin{array}{l}\text { Moving legs (walking, } \\
\text { stretching) relieves } \\
\text { discomfort }\end{array}$ & 65 & 18.4 & 60.2 & 82 & 21.5 & 60.3 \\
\hline $\begin{array}{l}\text { Symptoms are more } \\
\text { pronounced at bedtime or } \\
\text { during prolonged sitting }\end{array}$ & 55 & 15.5 & 50.9 & 65 & 17.0 & 47.8 \\
\hline $\begin{array}{l}\text { In the evening, complaints } \\
\text { get worse }\end{array}$ & 24 & 6.8 & 22.2 & 37 & 9.7 & 27.2 \\
\hline
\end{tabular}


A childhood RLS is decisive if all four of the above conditions are met- as basic criteria - and the child concerned is able to describe the complaints in his or her own words. An examination of the supporting criteria is necessary when only three of these four main criteria are fulfilled. At least two of these must be met:

- sleep disorder

- a close blood relative (biological parent, sibling) has a definite diagnosis of RLS

- indicates 5 or more sleep movement indexes per hour during instrumental sleep examination (actigraphy, polysomnography)

RLS is likely to be diagnosed if, by the four criteria, there is a definite diagnosis of RLS in a blood relative, or if the child has discomfort while standing or sitting for a longer time; this worsens with further rest and in the evening, and movement eases it.

The diagnosis of RLS is possible if the child has periodic limb movements in sleep, and a definite diagnosis of RLS has been made in one of the blood relatives.

The Körmend Growth Study sleep questionnaire can be used to test the existence of the four basic criteria and for reliably diagnosed RLS among relatives.

According to the completed questionnaires, all the four basic criteria were fulfilled in 25 children (Figure 3). This represents $3.4 \%$ of the total sample $(\mathrm{n}=736)$.

7 of the 354 boys ( $2.0 \%$ of the boys) and 18 of the 382 girls ( $4.7 \%$ of the girls) met all the four prerequisites. The average age of the children was 9.8 years with a standard deviation of 2.6. Of these 25 children, 12 (48\%) had rare RLS symptoms, 8 (32\%) had occasional symptoms (1-2 times a month), and $5(20 \%)$ complained of frequent (daily or multiple weekly) feelings of discomfort typical of RLS.

Only one respondent reported a definite diagnosis of RLS in close blood relations. This girl had unpleasant affections on a daily or weekly basis. 


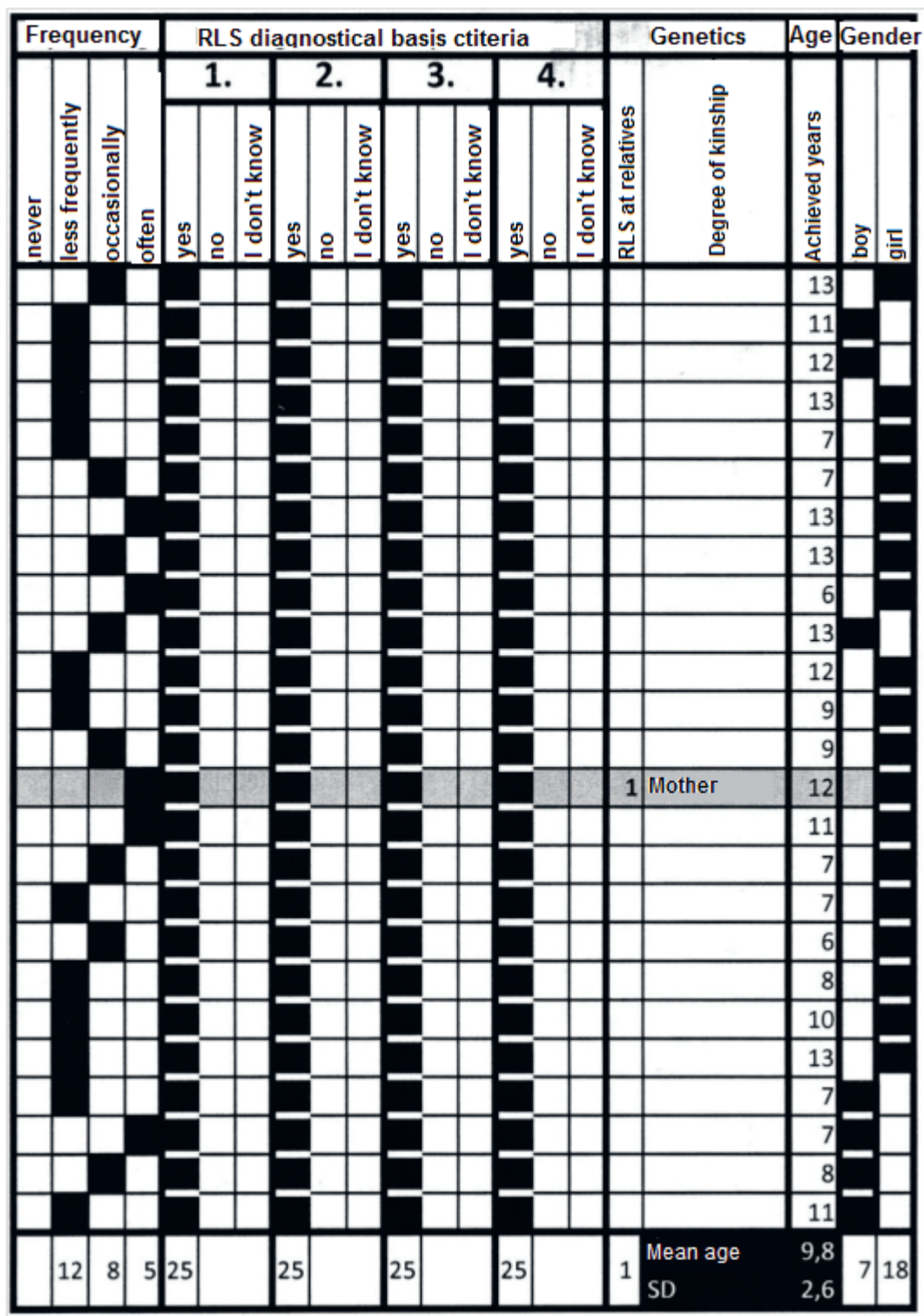

Figure 3. Responses in the case of meeting the four major RLS diagnostic criteria 


\section{Serious sleep disorders in the family}

21 children (2.9\% of the total sample) reported insomnia occurring in a narrow family circle, with only 8 relatives of children ( $1.1 \%$ of the total sample) reporting a definite case of RLS.

The family member suffering from insomnia was the mother in 6 cases, the father in 4 cases, the grandmother in 4 cases, the grandfather in 2 cases, the grandparent in 3 cases, the great-grandmother in 1 case and the nephew in 1 case.

The family member with confirmed RLS was the mother in 3 cases, the father in 3 cases, the grandfather in 1 case, and the grandparent in 1 case.

These low numbers and rates reflect neither the endemic insomnia (13$33 \%$ of the population) [16] nor the expected $10-22 \%$ occurrence of RLS [29, 42]. Assuming that the respondents were at least aware of their parents' and grandparents' sleeping difficulties, then, based on the 736 completed questionnaires, the direct relatives should have been affected by insomnia in 600-1500 cases and by RLS in $450-950$ cases.

There is a significant difference between the results of the Körmend Growth Study and the international literature in two aspects. This difference is due to sampling errors and limitations. In particular, the questionnaire might be incomplete as far as the questions requiring the respondents' own answers are concerned. In addition, in many cases, RLS had not been diagnosed [45] as the disease latency is high.

Therefore, we cannot draw far-reaching conclusions about the genetic relationship from the results of the Sleep Research Section of the Körmend Growth Study.

\section{Relationships between growth pain and restless leg syndrome (RLS)}

18 children (2.5\%) of the 736 who completed the questionnaires experienced frequent daily growth pain; 9 of them were boys and 9 were girls. Of these 18 persons, 8 (44.4\%) had frequent, 3 (16.7\%) occasional, 2 (11.1\%) less frequent growth pains; 4 (22.2\%) had previously reported unusual, strange, tickling, numb, pulling, drilling, grasping discomfort in the lower limbs. One person (5.6\%) did not answer this question.

The gender distribution is shown in Figure 4. Of the 9 boys who recorded frequent growth pain, 4 (44.4\%) had RLS-like symptoms often, 1 (11.1\%) occasionally, 1 (11.1\%) rarely, 3 (33.3\%) never. Of the 9 girls who reported frequent growth pains, 4 (44.4\%) had frequent complaints specific to RLS, in $2(22.2 \%)$ 
these were uncommon, $1(11.1 \%)$ had them less often and $1(11.1 \%)$ never. One girl did not answer this question.

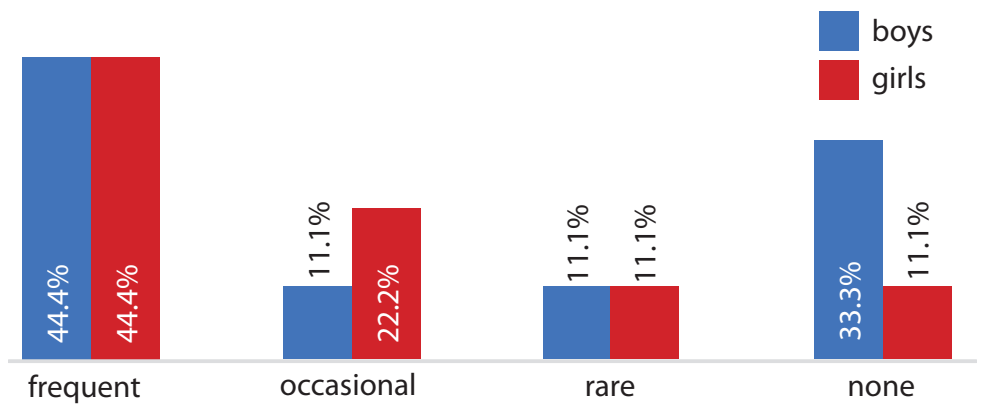

Figure 4. Incidence of RLS-related symptoms in children in Körmend with frequent growth pain

Of the 736 primary school-age respondents, 97 (13.2\%) experienced occasional growth pains (1-2 times a month). Of these, 44 were boys (45.4\%) and 53 were girls (54.6\%).

Among those experiencing growth pain 1-2 times a month, one person (1.0\%) reported frequent, $36(37.1 \%)$ intermittent, $26(26.8 \%)$ rare RLS complaints, and $32(33.0 \%)$ did not have them at all; 2 children $(2.1 \%)$ did not answer the question.

Of the 44 boys reporting uncommon growth pain, none reported frequent RLS, in 17 (38.6\%) the symptoms were uncommon, in 7 (15.9\%) rare, 19 (43.2\%) had no RLS complaints, 1 person (2.3\%) did not answer the question. Of the 53 girls with occasional growth pain, 1 (1.9\%) had frequent, $19(35.8 \%)$ occasional, 19 (35.8\%) rare RLS complaints. 13 (24.5\%) had them never, and 1 person $(1.9 \%)$ did not answer the question. The distribution by gender is shown in Figure 5.

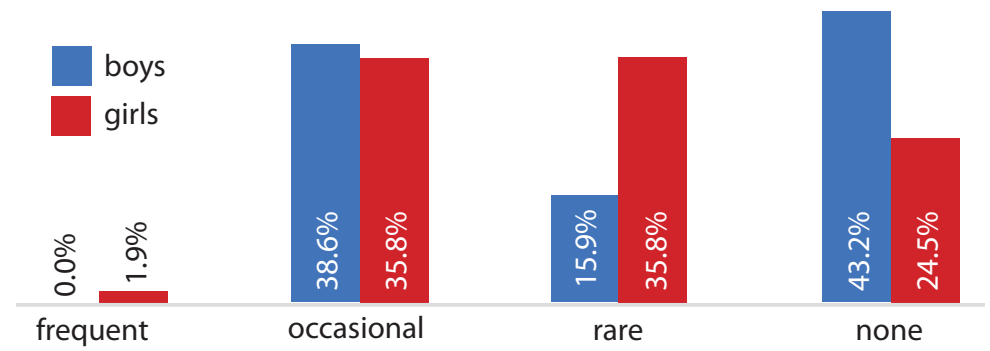

Figure 5. Occurrence of RLS-related symptoms in children with occasional growth pain in Körmend 
Of the 736 respondents, 237 children (32.2\%) experienced growth pain rarely (less than once a month). Of these, 112 (47.3\%) were boys and $125(52.7 \%)$ were girls.

Of those who rarely experience growth pain, only $2(0.8 \%)$ reported frequent symptoms of RLS; 15 (6.3\%) had them occasionally, 108 (45.6\%) rarely, and 108 (45.6\%) never had a symptom suggestive of RLS. 4 persons (1.7\%) did not answer the question.

Of the boys who rarely experienced growth pain, none had frequent RLS symptoms, 5 (4.5\%) had them occasionally, 52 (46.4\%) rarely, 53 never. 2 persons (1.8\%) left the question unanswered.

Of girls who rarely experienced growth pain, 2 (1.6\%) had frequent RLS symptoms, $10(8.0 \%)$ had them occasionally, $56(44.8 \%)$ rarely, $55(44.0 \%)$ had never had such complaints. 2 girls (1.6\%) did not answer the question.

The distribution of the above data by gender is shown in Figure 6 .

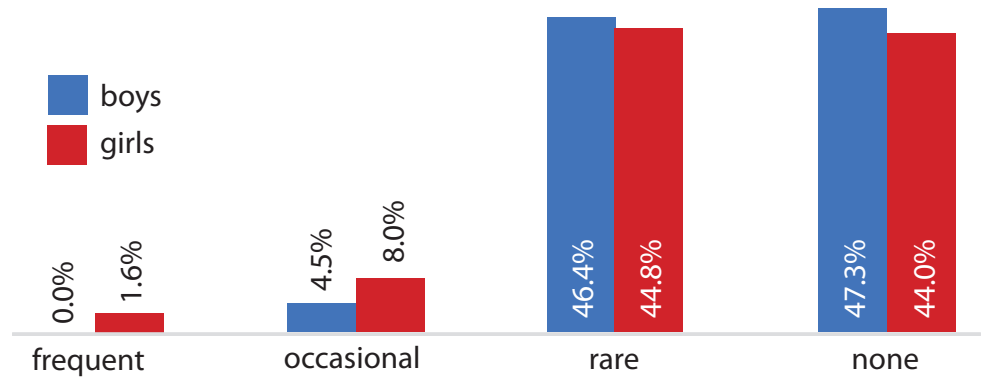

Figure 6. Incidence of RLS-related symptoms in children with rare growth pain in Körmend

Of the 736 respondents, 379 children (51.5\%) had never experienced growth pain. Of these, 184 were boys (48.5\%) and 195 were girls (51.5\%).

Among those not experiencing growth pain, $3(0.8 \%)$ reported frequent RLS; for 4 (1.1\%) it was uncommon, for $36(9.5 \%)$ rare, and $336(88.7 \%)$ had never experienced it. 1 person $(0.3 \%)$ did not answer the question.

Among boys without growth pain, 2 (1.1\%) reported frequent RLS symptoms, 1 person (0.5\%) reported occasional complaints, 18 (9.8\%) reported rare symptoms, and $162(88.0 \%)$ did not have them at all. 1 person $(0.5 \%)$ did not answer this question.

In girls who did not experience growth pain, $1(0.5 \%)$ had RLS symptoms frequently, 3 (1.5\%) occasionally, 8 (4.1\%) rarely, 174 (89.7\%) never.

The above results by gender are presented in Figure 7 . 


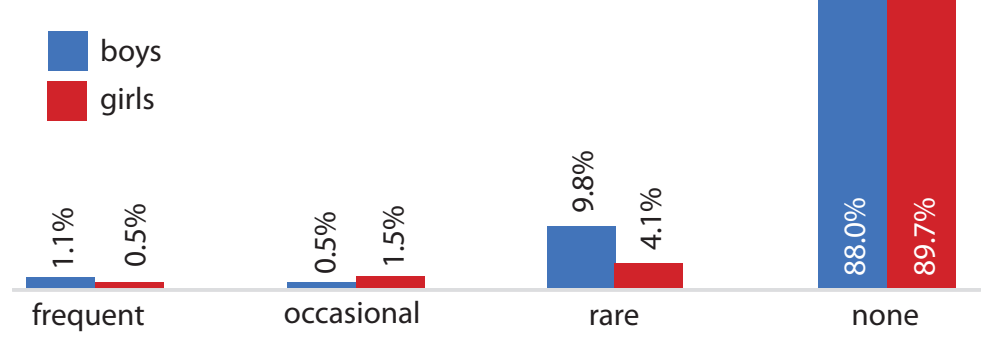

Figure 7. Occurrence of RLS-related symptoms in children in Körmend, not affected by growth pain

\section{Occurrence of iron deficiency and iron deficiency anaemia}

Iron deficiency was reported in 79 children (10.7\%), - 39 boys ( $11.0 \%$ of boys, mean age $9.8 \pm 2.4$ years $)$ and 40 girls ( $10.5 \%$ of girls, mean age: $11.0 \pm 2.7$ years).

Iron deficiency anaemia was found in 8 children (1.1\%). The ratio is $0.8 \%$ ( 3 persons) for boys and $1.3 \%$ ( 5 persons) for girls.

In children with iron deficiency, 1 (1.3\%) complained of common symptoms of RLS, for 12 (15.2\%) they were uncommon, for 19 (24.0\%) rare, 47 (59.5\%) had them never.

Of the iron deficient boys, 1 (2.6\%) complained of frequent RLS symptoms, 5 (12.8\%) occasionally, 7 (17.9\%) rarely, 26 (66.7\%) not at all.

None of the iron-deficient girls reported frequent RLS symptoms, 7 (17.5\%) had them occasionally, 12 (30.0\%) rarely, 21 (52.5\%) never complained.

The frequency of RLS symptoms in iron deficient children is shown in Figure 8. 


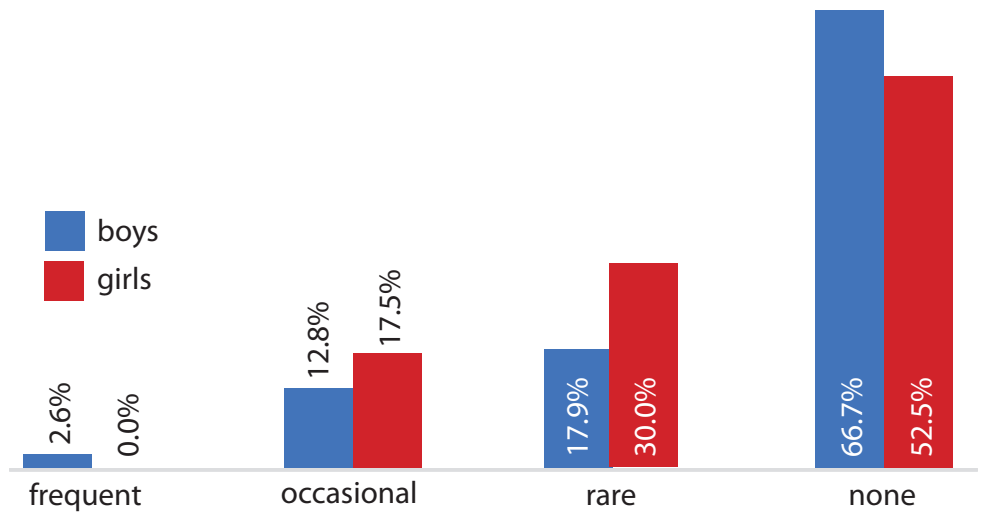

Figure 8. Incidence of RLS symptoms in iron deficient children in Körmend

Correlation between iron deficiency and iron deficiency anaemia and the restless leg syndrome

None of the anaemic children reported frequent or intermittent RLS, 3 (37.5\%) had it rarely, and $5(62.5 \%)$ never.

Of the 3 anaemic boys, 1 (33.3\%) had it rarely, 2 (66.6\%) had never experienced RLS.

Of the 5 anaemic girls, $2(40.0 \%)$ had it rarely, $3(60.0 \%)$ never reported any evidence of RLS.

The representation by gender is shown in Figure 9 .

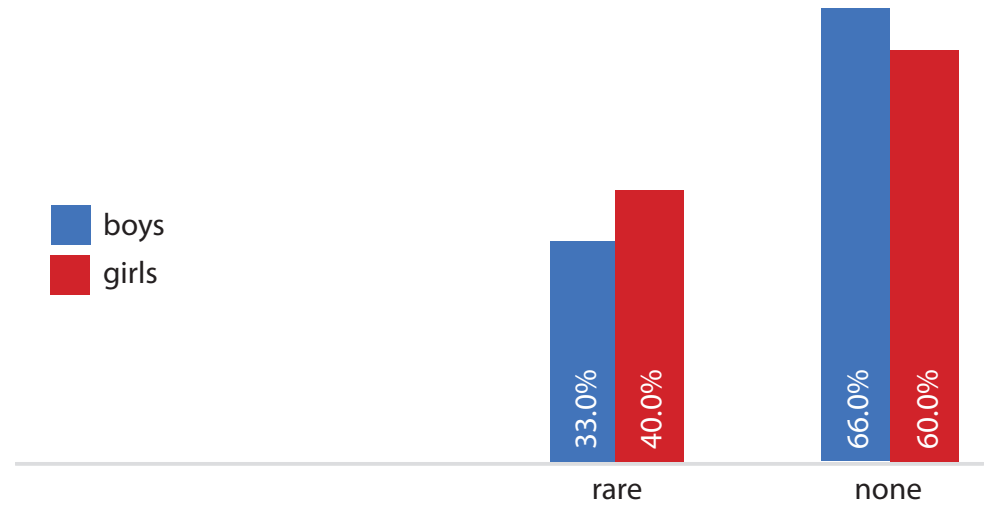

Figure 9. Incidence of RLS symptoms in anaemic children 
In the summarizing Figure 10 the incidence of growth pain and its frequency by gender is shown.

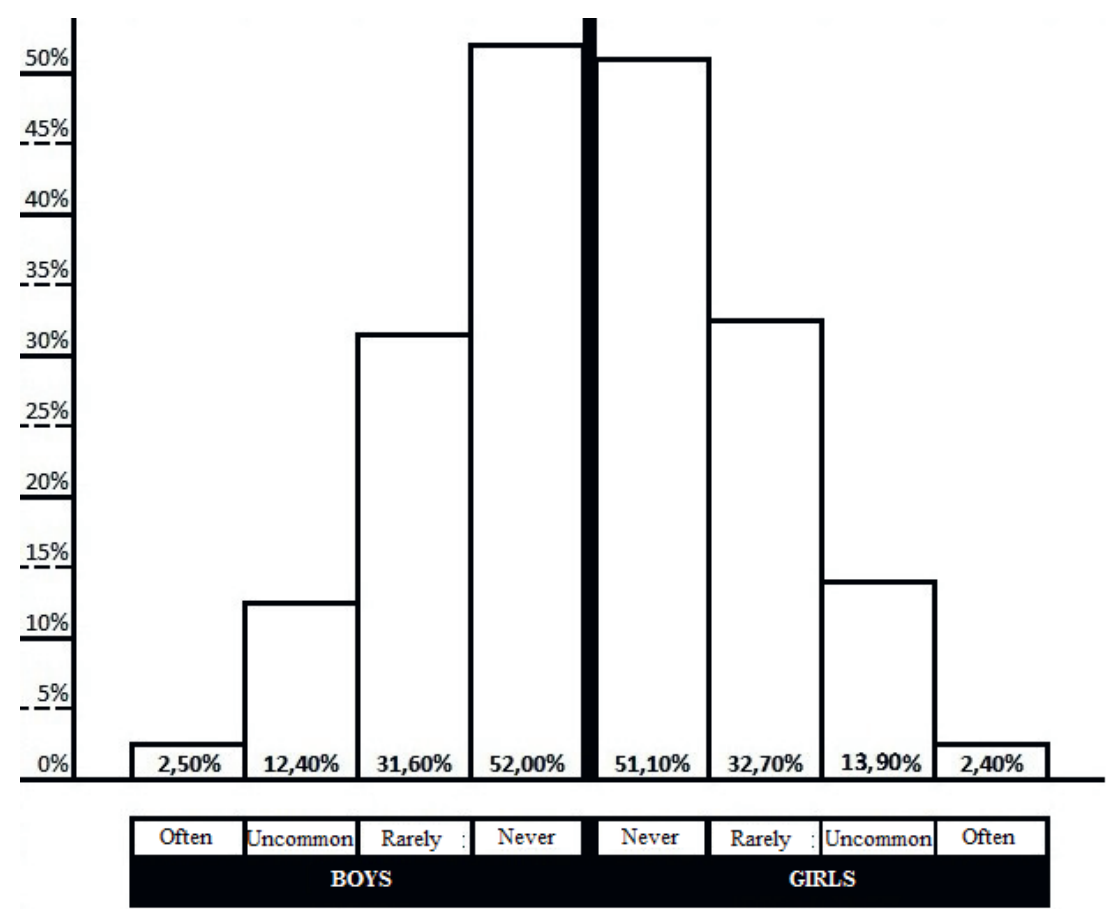

Figure 10. Incidence and severity of childhood growth pain by gender

\section{DISCUSSION}

The survey among primary school age children in Körmend can be considered reliable for lifetime prevalence. According to Picchietti and Stevens [41], negligible unprecedented growth pains appear even at the age of 14. According to the results of Van Dijk et al. [55], the lifetime prevalence of growth pain was $38 \%$ in boys and $37 \%$ in girls - less than half of the number of samples in the Körmend examination. In the study of Evans and Scutter [23], on the other hand, they used an almost double number of subjects compared to the Körmend study and found a standard deviation of 3 to $49 \%$ in the incidence of growth pain and estimated an average lifetime prevalence of $36.9 \%$. The results of Körmend showed a lifetime prevalence of $48.0 \%$ in girls and $48.9 \%$ in boys. This is on average $10 \%$ higher than in the literature data mentioned above. This may be due to the limitations of the questionnaire (striving for conciseness) - 
mapping of growth pains has been overshadowed by questions about RLS and, therefore, has not been included in the recommendations of Peterson [39] and Evans [24] about 4 basic, 4 ancillary and 4 negative questions. It is likely that parents attributed other childhood limb pain to growth pain, resulting in many false positives. Growth pains in childhood, like the restless leg syndrome and periodic limb movements in sleep, are characterized by diurnality: they occur from the bedtime in the evening and may wake children at night. Persistent pain, which appears to be without cause, can be assumed to be remembered by parents. Nonetheless, it can be assumed that especially parents who rarely record growth pain (32.3\%, the largest group in the sample) confused the existing symptoms with other limb pain for other reasons. This assumption is reinforced by the finding of Badali et al. [6] that children have consistently retained their painful experiences over time. According to Chambers et al. [14], parents' assessment and their children's experiences are consistent, therefore, parental report [54] might be a useful tool for assessing childhood sleep health disorders.

Concerning RLS, 14 out of 736 patients (2.0\%) had it frequently, $57(7.7 \%)$ 1-2 times a month, 173 (23.5\%) less frequently, 482 children (65.5\%) had never experienced the disease. A total of 254 elementary school children (34.5\%) reported ever occurring paraesthesias suggesting RLS. 32.5\% of boys and 36.4\% of girls experienced RLS. Based on the answers of the four basic criteria, 25 children (3.4\%) have a definite diagnosis of RLS. 7 (2.0\%) boys and 18 (4.7\%) girls gave a positive answer to all four basic criteria. 2.35 times more girls fulfilled the four conditions than boys, which showed a significant difference in the definite RLS diagnoses between boys and girls. Some studies report no gender differences [40], while others, although to a lesser extent, also showed a significantly higher prevalence among girls [61]. The proportions found in the Körmend study are consistent with the literature for boys [40, 61], but much higher for girls. To explain this more precisely, it may be necessary to analyse other age groups (kindergarten and high school students).

Of the 736 respondents, only $2.9 \%$ mentioned sleep disorders among the relatives of children, and only $1.1 \%$ had a known confirmed diagnosis of RLS. Of the 25 children with a definite RLS diagnosis based on the questionnaire, only one girl had a family accumulation. In this case, the child's relative afflicted by RLS was her mother, and the child frequently (daily or several times a week) developed symptoms of RLS. Some studies have shown genetic association in approximately $70 \%$ of children with a definite diagnosis of RLS [40]. The results of the Körmend study do not justify this degree of genetic determination. The 
low numbers and rates are not consistent with either RLS $[29,40,42]$ or predicted prevalence of sleep disorders [16] among blood relatives. Assuming that the respondents were at least aware of their parents' and grandparents' sleep patterns and any disturbances, there would be 450-950 individuals with RLS among the direct relatives of the 736 children and between $600-1500$ persons with insomnia. There are two scales difference from the literature, due to the limitations and error of sampling. Filling the questionnaire was optional and, as a result, many people probably did not pay enough attention to answering the questions, especially where they had to be written by themselves. In addition, the very latent presence of RLS has contributed to the underdiagnosis of the disease [45].

According to the responses, $2.5 \%$ of children often had growth pains, and $44.4 \%$ of them had frequent RLS complaints. There was no significant difference between boys and girls.

People who experience growth pain only occasionally also notice RLS symptoms less often. Among them, the most populous group consisted of those who occasionally or rarely experienced RLS. We found a significant difference between boys (54.6\%) and girls (71.6\%) at $90 \%$ confidence level.

Children who reported rarely occurring growth pain had uncommon or infrequent RLS symptoms: $50.9 \%$ in boys and $52.8 \%$ in girls. The difference between the genders was not statistically detectable. RLS symptoms were common between $0 \%$ and $0.8 \%$ of them.

Of those who had never experienced growth pain, $88.7 \%$ had no documented RLS complaints. $11.4 \%$ of boys and $6.1 \%$ of girls had RLS symptoms, and the gender difference was found to be significant with $90 \%$ confidence level. The causes of this phenomenon need to be clarified.

Earlier occurring growth pain was frequently reported in $16 \%$ of children with a definite RLS diagnosis, $32 \%$ had it occasionally, and $44 \%$ rarely. In children with a definite diagnosis of RLS, only $8 \%$ had no previous history of growth pain.

To accurately map the incidence of iron deficiency, laboratory blood analysis should have been included, which was not an option in the Körmend study due to its high cost. Therefore, it was concluded from the questionnaire replies. The reliability of this was demonstrated by the fact that iron deficiency reporters also described the name of the iron product administered for treatment. The incidence of iron deficiency and anaemia by gender is shown in Figure 11.

In population-based studies, $9-11 \%$ of children have been iron deficient and $2-5 \%$ anaemic [33]. Our data on iron deficiency were consistent with 
the results of the publications, but we found half of the minimum value for iron deficiency anaemia. This is partly because parents are often unaware of the existence of anaemia; they know only of iron deficiency. Another possible explanation is that the work of the Hungarian Health Visitor Service, the efficiency of which is unique in the world, has reduced the incidence of anaemia below the international level.

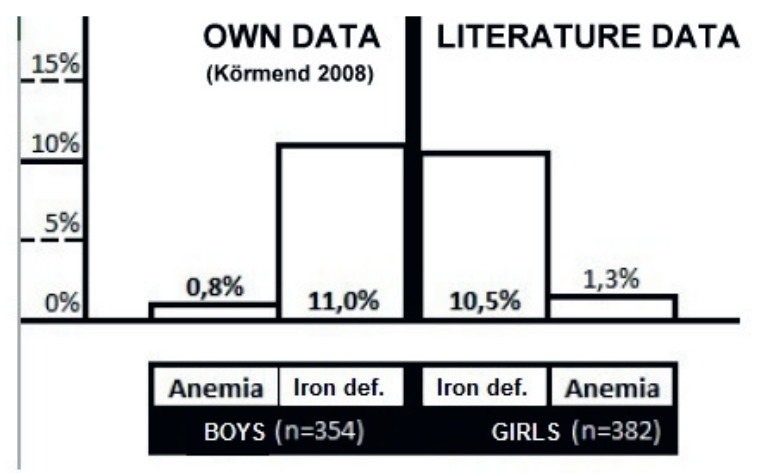

Figure 11. Incidence of iron deficiency and anaemia among primary school children in Körmend. While the prevalence of iron deficiency is congruent with the literature data, anemia prevalence is scarcely the half of the internationally published percentages.

During the evaluation of the questionnaires, $40.5 \%$ of iron deficient children had symptoms suggestive of RLS. Most of them (15.2\% and $24.0 \%$ ) occasionally or rarely experienced any discomfort in the limbs. Common symptoms were seen only in $2.6 \%$ of iron deficient boys. Figure 12 illustrates the incidence of RLS in boys and girls with iron deficiency and anaemia.

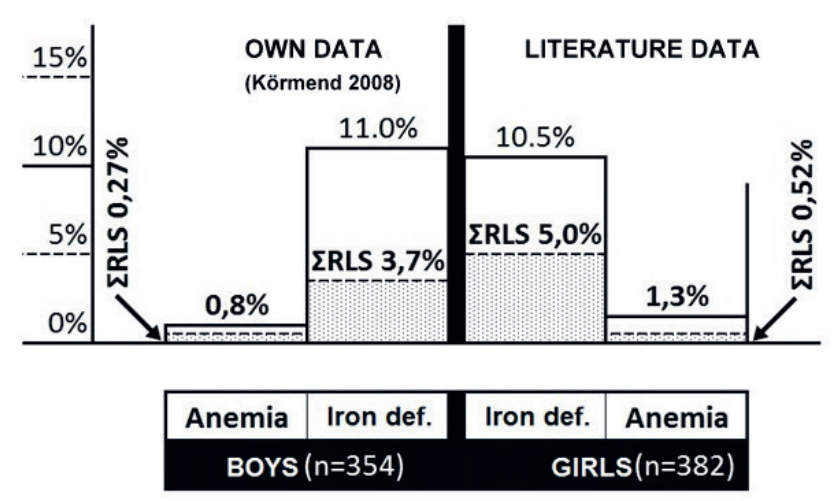

Figure 12. RLS in iron deficient and anaemic children in Körmend. The dotted area represents the percentage/proportion among boys and girls diagnosed with iron deficiency and anemia, respectively. 
The association between peripheral iron concentration and the presence and severity of RLS has been known for a long time, even so there is no clear evidence of an increased incidence of the restless leg syndrome in iron deficient or anaemic patients. One study found that in patients with iron deficiency anaemia, clinically significant RLS occurs nine times as often as in the general population [3]. The Sleep Questionnaire of the Körmend Growth Study did not allow the distinction between the more severe and the lighter versions of RLS. Based on their cumulative value, $40.5 \%$ of primary school children with iron deficiency in Körmend have RLS (33.3\% of boys and $47.5 \%$ of girls). This shows that iron deficiency is one scale higher in RLS than in the general population. In addition, it can be shown that, at $80 \%$ confidence, iron deficient girls are significantly more likely to have RLS than boys.

Due to the low number of anaemic children in the sample, it was not possible to statistically investigate any further relevant questions about them.

\section{REFERENCES}

1. Abbassi V. (1998). Growth and normal puberty. Pediatrics, 102 (2 Pt 3), 507-513.

2. Albanese M., Placidi F., Romigi A., Liguori C., Marchi A., Mercuri N.B., Marciani M.G., Izzi F. (2015). Refractory restless legs syndrome remitting after dual kidney transplantation. Parkinsonism Relat Disord, 21(1), 81-83. https:// doi.org/10.1016/j.parkreldis.2014.10.023

3. Allen R.P., Auerbach S., Bahrain H., Auerbach M., Earley C.J. (2013). The prevalence and impact of restless legs syndrome on patients with iron deficiency anemia. Am J Hematol, 88(4), 261-264. https://doi.org/10.1002/ajh.23397

4. Allen R.P., Picchietti D., Hening W.A., Trenkwalder C., Walters A.S., Montplaisir J. (2003). Restless legs syndrome: diagnostic criteria, special considerations, and epidemiology. A report from the restless legs syndrome diagnosis and epidemiology workshop at the National Institutes of Health. Sleep Med, 4, 101-119. https://doi.org/10.1016/S1389-9457(03)00010-8

5. American Academy of Sleep Medicine (2014). International Classification of Sleep Disorders, 3rd ed., Darien, Illinois.

6. Badali M.A., Pillai R.R., Craig C.D., Giesbrecht K., Chambers C.T. (2000). Accuracy of children's and parents' memory for a novel painful experience. Pain Res Manage, 4(2), 161-168. https://doi.org/10.1155/2000/705436

7. Berger D. (2014). Leg discomfort: beyond the joints. Med Clin North Am, 98(3), 429-444. https://doi.org/10.1016/j.mcna.2014.01.004

8. Bódizs R. (2000). Alvás, álom, bioritmusok. Medicina Könyvkiadó Rt., Budapest. 
9. Buda B.L., Tóth G.A. (2005). Rejtőzködő népbetegség: Alvásfüggő mozgászavarok (II). Folia Anthrop, 3, 25-26.

10. Buda B.L., Tóth G.A. (2008). Restless legs syndrome and obesity in Hungarian young adult men. Papers on Anthrop 17, 38-48.

11. Buda B.L., Tóth G.A., Buda B.K., Borbás T. (2006). Sleep and wakefulness among polytechnic high school boys in Western Hungary. Journal of Sleep Res, 15. Suppl. 1, 82-83.

12. Buda B.L., Tóth G.A., Gdynia H-J. (2008). Nyugtalan törzs szindróma - fából vaskarika? Orvostudományi Értesítő, 81(3), 188-191.

13. Buda B.L., Marksz L., Tóth G.A. (2016). Alvó város - a Körmendi Növekedésvizsgálat (2008) szomnológiai eredményeiből. Folia Anthrop, 15, 29-44.

14. Chambers C.T., Reid G.J., Craig K.D., McGrath P.J. (1998). Agreement between child and parent reports of pain. Clin J Pain, 14, 336-342. https://doi. org/10.1097/00002508-199812000-00011

15. Chen X., Beydoun M.A., Wang Y. (2008). Is sleep duration associated with childhood obesity? A systematic review and meta-analysis. Obesity (Silver Spring), 16(2), 265-274. https://doi.org/10.1038/oby.2007.63

16. Cunnington D., Junge M.F., Fernando A.T. (2013). Insomnia: prevalence, consequences and effective treatment. Medical Journey of Australia, 199(8), Suppl., 36-40. https://doi.org/10.5694/mja13.10718

17. Currie A., Cappuccio F.P. (2007). Sleep in children and adolescents: a worrying scenario: can we understand the sleep deprivation-obesity epidemic? Nutr Metab Cardiovasc Dis, 17(3), 230-232. https://doi.org/10.1016/j. numecd.2006.10.007

18. Dosman C., Witmans M., Zwaigenbaum L. (2012). Iron's role in paediatric restless legs syndrome - a review. Paediatr Child Health, 17(4), 193-197. https:// doi.org/10.1093/pch/17.4.193

19. Duchamp R.G. (1823). Maladies de la croissance. Imprimerie de Fain, Place de l'Odéon, Paris.

20. Durmer J.S., Quraishi G.H. (2011). Restless legs syndrome, Periodic leg movements, and periodic limb movement disorder in children. Pediatric Clinics, 58(3), 591-620. https://doi.org/10.1016/j.pcl.2011.03.005

21. Eiben O. (2003). Körmend ifjúságának biológiai fejlettsége a 20. század második felében. Körmendi Füzetek, Körmend.

22. Eiben O.G., Tóth G.A. (2005). A Hungarian case of secular growth changes: the Körmend Growth Study. Ind J of Phys Anthrop and Hum Gen, 24(2), 99-108.

23. Evans A.M., Scutter S.D. (2004). Prevalence of growing pains in young children. J Pediatr, 145, 255-258. https://doi.org/10.1016/j.jpeds.2004.04.045

24. Evans A.M. (2008). Growing pains: contemporary knowledge and recommended practice. J Foot Ankle Res, 1(1), 4. https://doi.org/10.1186/1757-1146-1-4

25. Ferri R., Rundo F., Zucconi M., Manconi M., Bruni O., Ferini-Strambi L., Fulda S. (2015). An evidence-based analysis of the association between periodic 
leg movements during sleep and arousals in restless legs syndrome. Sleep, 38(6), 1, 919-924. https://doi.org/10.5665/sleep.4740

26. Isak B., Agan K., Ergun A., Cakkalkurt A., Uluc K., Tanridag T., Us O. (2011). Where is the core of the volcano? The undetermined origin of primary restless legs syndrome. Int J Neurosci, 121(3), 130-136. https://doi.org/10.3109/00207 454.2010.537413

27. Joosten K.F., Larramona H., Miano S., van Waardenburg D., Kaditis A.G., Vandenbussche N., Ersu R. (2017). How do we recognize the child with OSAS? Pediatr Pulmonol, 52(2), 260-271. https://doi.org/10.1002/ppul.23639

28. Kim S., Kim K.T., Motamedi G.K., Cho Y.W. (2020). Clinical characteristics of Korean pediatric patients with restless legs syndrome. Sleep Med, 69, 14-18. https://doi.org/10.1016/j.sleep.2019.12.016

29. Köves P. (1998). Az obstruktív alvási szindróma. Springer, Budapest, 38-70.

30. Levesque R. (2007). SPSS programming and data management: A Guide for SPSS and SAS users (4th ed.) SPSS Inc., Chicago, Illinois.

31. Lim Y.M., Chang S.E., Chung S., Kang B.H., Kim K.K. (2012). Small fiber function in drug naïve patients with idiopathic restless legs syndrome. J Clin Neurosci, 19(5), 702-705. https://doi.org/10.1016/j.jocn.2011.07.043

32. Lindner A.V. (2011). A krónikus veseelégtelenség pszichoszociális szempontjai - A nyugtalan láb szindróma és az alvás alatti periodikus lábmozgászavar. Semmelweis Egyetem Mentális Egészségtudományok Doktori Iskola, Budapest. PhD Thesis.

33. Looker A.C., Dallman P.R., Carroll M.D., Gunter E.W., Johnson C.L. (1997). Prevalence of iron deficiency in the United States. JAMA, 277(12), 973-976. https://doi.org/10.1001/jama.1997.03540360041028

34. Lugaresi E., Cirignotta F., Coccagna G., Montagna P. (1986). Nocturnal myoclonus and restless legs syndrome. Adv Neurol, 43, 295-306.

35. Lyytikäinen P., Rahkonen O., Lahelma E., Lallukka T. (2011). Association of sleep duration with weight and weight gain: a prospective follow-up study. J Sleep Res, 20(2), 298-302. https://doi.org/10.1111/j.1365-2869.2010.00903.x

36. Novak M., Winkelman J., Unruh M. (2015). Restless legs syndrome in patients with chronic kidney disease. Seminars in Nephrology, 35(4), 347-358. https:// doi.org/10.1016/j.semnephrol.2015.06.006

37. Ondo W.G. (2014). Restless legs syndrome: pathophysiology and treatment. Curr Treat Options Neurol, 16(11), 317. https://doi.org/10.1007/ s11940-014-0317-2

38. Pérez-Díaz H., Iranzo A., Rye D.B., Santamaria J. (2011). Restless abdomen: a phenotypic variant of restless legs syndrome. Neurology, 77(13), 1283-1286. https://doi.org/10.1212/WNL.0b013e318230207a

39. Peterson H. (1986). Growing pains. Pediatr Clin North Am, 33(6), 1365-1372. https://doi.org/10.1016/S0031-3955(16)36147-8 
40. Picchietti D., Allen R.P., Walters A.S., Davidson J.E., Myers A., Ferini-Strambi L. (2007). I. Restless legs syndrome: prevalence and impact in children and adolescents - the Peds REST study. Pediatrics, 120, 253-266. https://doi.org/10.1542/ peds.2006-2767

41. Picchietti D.L., Stevens H.E. (2008). Early manifestations of restless legs syndrome in childhood and adolescence. Sleep Med, 9, 770-781. https://doi. org/10.1016/j.sleep.2007.08.012

42. Purvis C., Phillips B., Asher K. et al. (1997). Self-reports of restless legs syndrome: 1996 Kentucky Behavioral Risk Surveillance Survey. Sleep Research, 26, 474.

43. Rajaram S.S., Walters A.S., England S.J., Mehta D., Nizam F. (2011). Some children with growing pains may actually have restless legs syndrome. Pediatr Clin North Am, 58(3), 591-620.

44. Remenyi D., Onofrei G., English J. (2011). An introduction to statistics using Microsoft Excel - Sonning Common, Academic Conferences and Publishing International.

45. Salas R.E., Kwan A.B. (2012). The real burden of restless legs syndrome: clinical and economic outcomes. The American Journal of Managed Care, 18 (9 Suppl), 207-212.

46. Sandyk R. (1985). The endogenous opioid system in neurological disorders of the basal ganglia. Life Sci, 37(18), 1655-1663. https://doi.org/10.1016/0024-3205(85)90292-9

47. Tinning F.B., Hestbæk L., Andersen A.N. (2017). Vokseværk er velkendt, men årsagen er fortsat uklar. Ugeskr Laeger, 179(14), 2-5.

48. Tóth G., Suskovics Cs., Buda B. (2009). A gyermekek növekedésének szekuláris trendje: Körmend 1958-2008. Magyar Sporttudományi Szemle, 10(2), 56-57.

49. Tóth G., Suskovics Cs. (2011). A BMI értékei a 3-18 éves Nyugat-Magyarországi gyermekeknél. In: Strédl T., Nagy M. (szerk.): Egymás mellett vagy együtt?! Selye János Egyetem, Komárom. CD.

50. Tóth G., Suskovics Cs. (2020). Változások a gyermekek növekedésében (19582018). MUZAKT IV. Nové Zámky. In press.

51. Trenkwalder C. (1998). Restless Legs Syndrom. Springer-Verlag, Berlin.

52. Trenkwalder C., Allen R., Högl B., Paulus W., Winkelmann J. (2016). Restless legs syndrome associated with major diseases - A systematic review and new concept. Neurology, 86(14). https://doi.org/10.1212/WNL.0000000000002542

53. Uziel Y., Hashkes P.J. (2007). Growing pains in children. Pediatr Rheumatol Online J, 19(5), 5. https://doi.org/10.1186/1546-0096-5-5

54. Vaher H., Kasenõmm P., Vasar V., Veldi M. (2013). A survey of parentally reported sleep health disorders in Estonian 8-9 year old children. BMC Pediatr, 13, 200. https://doi.org/10.1186/1471-2431-13-200 
55. Van Dijk A., McGrath P.A., Pickett W., Van Den Kerkhof E.G. (2006). Pain prevalence in nine- to 13-year-old school children. Pain Res Manag, 11(4), 234-240. https://doi.org/10.1155/2006/835327

56. Veldi M., Ani R., Vaher H., Eller T., Hion T., Aluoja A., Vasar V. (2010). Obstructive sleep apnea syndrome (OSAS): Pathophysiology in Estonians. Pathophysiology, 3, 219-223. https://doi.org/10.1016/j.pathophys.2010.01.001

57. Véli Gy. (1936). A kaposvári óvodás és elemi iskolás gyermekek testméretei. Iskola és Egészség, 3, 112-124.

58. Walters A.S., Gabelia D., Frauscher B. (2013). Restless legs syndrome (Willis-Ekbom disease) and growing pains: are they the same thing? A side-by-side comparison of the diagnostic criteria for both and recommendations for future research. Sleep Med, 14(12), 1247-1252. https://doi. org/10.1016/j.sleep.2013.07.013

59. Webb W.B., Dinges D.F. (1989). Cultural perspectives on napping and the siesta. In: Dinges D.F., Broughton R.J. eds.: Sleep and alertness: Chronobiological, behavioral and medical aspects of napping. Raven Press, New York, 247-266.

60. Winsper C., Tang N.K. (2014). Linkages between insomnia and suicidality: prospective associations, high-risk subgroups and possible psychological mechanisms. Int Rev Psychiatry, 26(2), 189-204. https://doi.org/10.3109/09540261. 2014.881330

61. Xue R., Liu G., Ma S., Yang J., Li L. (2015). An epidemiologic study of restless legs syndrome among Chinese children and adolescents. Neurol Sci, 36(6), 971-976. https://doi.org/10.1007/s10072-015-2206-1

\section{Address for correspondence:}

Gábor A. Tóth

ELTE Savaria University Centre, Department of Biology

9700 Szombathely

Károlyi G. tér 4.

HUNGARY

E-mail: tgabor.humbiol@gmail.com 